\title{
Internationalization of an Entrepreneurial Services Company from the Arabian Gulf: The Case of Renaissance Services SAOG
}

\author{
Golam Mostafa Khan \\ Associate Professor of Management, College of Commerce and Economics \\ Sultan Qaboos University, Oman \\ E-mail: mostafa.khan@hotmail.com, gmkhan@squ.edu.om
}

Received: December 20, 2011

Accepted: February 29, 2012

Published: April 16, 2012

doi:10.5539/ijbm.v7n8p33

URL: http://dx.doi.org/10.5539/ijbm.v7n8p33

The author gratefully acknowledges the financial support for this research from Sultan Qaboos University.

\begin{abstract}
This case study profiles a company founded by an entrepreneur in Oman in the Arabian Gulf. Renaissance Services has grown from a small family-owned operation into a global company marketing services in industrial and commercial sectors. Case analysis raises issues about the validity, comprehensiveness, and applicability of current international business theory about psychic distance, the process of internationalization, and country-of-origin effects. In the face of apparent discrepancies between theory and practice suggested by this case, a call is issued for theoretical review and possible extension. This will accommodate new realities of global expansion by entrepreneurs operating from home countries which have been little studied in the past.
\end{abstract}

Keywords: Internationalization, Entrepreneurship, Psychic distance, Country-of-origin effects, Services, Oman, Oil and gas

\section{Introduction}

This paper presents a new case study of an entrepreneurial company based in the Arabian Gulf (hereafter 'the Gulf'). Renaissance Services Company (hereafter 'Renaissance') has achieved rapid international growth across world markets and is performing successfully despite difficult global market conditions. Renaissance operates in numerous business-to-business (B2B) sectors with a primary focus on the global oil and gas industries. Findings from this case provide a basis for re-examining accepted theories in the scholarly literature of international business (IB). Concerns will be addressed about the validity, comprehensiveness, and applicability of these theories in light of this new empirical evidence.

The research method used in this study is inductive analysis, moving from the reality of empirical case-based evidence toward a re-evaluation of existing theory. Thus, the case study will highlight some inconsistencies between established theory and the strategies and practices of a real-life company. While it is unusual and conceptually risky to challenge established theory on the basis of a single company example, this is the first in a series of studies of Gulf-based companies in a large-scale research project among a group of IB scholars. Subsequent studies will feature other new case studies of companies, revealing similar inconsistencies between IB theory and real-life practice. These include a Bahraini commercial bank (Khan et all, 2011), an Islamic investment bank operating globally from a base in the Gulf (Khan, 2012), as well as a Kuwaiti and a Saudi (Khan and Al Moharby, 2010) telecommunications providers. Our goal is to assemble a body of case-based evidence spanning several industries that form a solid argument for revisiting and possibly expanding current IB theories.

The paper proceeds as follows. First, three major research questions are presented, focusing attention on the three IB constructs. This is followed by a targeted literature review which provides a theoretical basis for subsequent case analysis. After presentation of the case study, findings are discussed by reference to the three constructs as a means of generating research propositions for further research.

\section{Approach and Method}

This paper demonstrates how companies operating outside the well-studied areas of North America, Western 
Europe, and Japan call into question the validity of some established IB theories. In this instance, questions are raised about the completeness and applicability of psychic distance theory and the internationalization path model. A need is also recognized to document and evaluate country-of-origin effects associated with less well-researched countries (such as Oman). In addition, it may be the case that current IB theory does not adequately capture the experience of service marketing companies, as opposed to manufacturers, when the former decide to go international. The desired outcome from this study is for IB scholars to reconsider current theoretical formulations in light of this new evidence from companies founded and operating in the Arabian Gulf.

Sources of data for this first case study include publicly available secondary materials and internal company documents. These were complemented by primary data collected during face-to-face interviews with the Chairman / founder and the CEO of Renaissance in Oman during 2008 and 2009. Their subjective opinions are cited in the case study to illustrate their reasoning behind decisions critical to the success of the company.

\section{Research Questions and Focused Literature Review}

During development of the case study, three theoretical questions focused the research effort:

a. How was psychic distance experienced by an entrepreneur who has built a family-based company into a global conglomerate?

b. During the rapid growth of this company, which stages of the internationalization path model were experienced?

c. What impact, if any, did country-of-origin have on the founder and his company's success?

The following sections present a focused literature review highlighting issues of relevance to later analysis of the new case study.

\subsection{Psychic distance}

Critical issues when going international are the differences (or similarities) that managers perceive when selecting countries for possible market entry and operations. Psychic distance (PD) refers to perceived similarities and differences in culture, political systems, education, and industrial progress between the home country of company managers and the proposed market of entry (Hallen and Wiedersheim-Paul 1984). According to PD theory, managers are less likely to enter country-markets which they perceive to be dissimilar from their home market (Johanson and Wiedersheim-Paul 1975; Jain 1989). Based on this model developed by members of the Uppsala School, general expectations can be formulated about how managers will select which country-market to target first; how to enter a market; what type and quantity of resources to commit; and how to manage further expansion into subsequent country-markets. These questions will be revisited in the theoretical discussion following the case study.

\subsection{Internationalization path model}

With regard to the internationalization process, several researchers have questioned the underlying 'stages' model of gradual expansion which is based on learning and experience in successive markets. These include Knight and Cavusgil (1996, 2004), Masen and Servais (1997), and Chetty and Campbell-Hunt (2004). Oviatt and McDougall (1994) questioned the relevance of such models in a world characterized by rapidly changing markets and technological environments. Fina and Rugman (1996) went further, arguing that internationalization stage models are too arbitrary. More recently, Liu et al. (2008) found that internationalization of Chinese private firms can only be partially explained by the Uppsala model. Similarly, Rui and Yip (2008) observed that large Chinese firms achieve their strategic goals for internationalization by using cross-border acquisitions, rather than by expanding through sequential stages of international expansion, as postulated by current theory. As the case study will demonstrate, expansion through mergers and acquisitions ( $M$ \& As) has been the preferred strategy for Renaissance which has grown rapidly from a home base in Oman.

\subsection{Country-of-origin effect}

The COO construct is routinely operationalized and communicated to consumers using the phrase "Made in..." and the country name (Amine 2008). Perceptions of country image are categorized and measured as favorable, neutral or unfavorable (Pappu et al. 2007). Orbaiz and Papadopoulos (2003) observed that key factors in 'product-country image' (PCI) are buyers' beliefs and attitudes toward a product's country-of-origin. Antecedents to PCI include animosity and ethnocentrism which may create unfavorable views of foreign-made products, as well as world mindedness which results in favorable views.

$\mathrm{COO}$ effects are relevant in the case of Renaissance since it is a company based in Oman, a large Arab country 
that is seldom in the international news. Strong positive $\mathrm{COO}$ associations between 'the Gulf' and 'oil' and 'Omani' and 'sea-faring' might be assumed to offer favorable COO effects to Renaissance. In contrast, negative associations with COO effects were experienced by Dubai Ports World (DPW), a company based in the UAE which attempted to buy port management contracts for six US ports in February 2006. This bid provoked a storm of public protest in the US about issues of potentially compromising national security. Concerns were raised about the nationality of the company (Emirati) and the fact that DPW is state-owned. Stereotyping by country-of-origin played a determinant role in causing this bid to fail, despite the fact that the UAE is a strategic ally of the US. Ironically, these port contracts had previously been foreign-owned by Peninsular and Oriental Steam Navigation Company (P\&O), a British firm which was taken over by DPW one month later in March 2006.

The following case study demonstrates how Renaissance, a company operating in the global B2B sector, has consistently sought out opportunities wherever the market potential is most attractive. Renaissance appears to have been unfettered by any considerations of perceived PD or COO effects, and has leapfrogged over traditionally-accepted stages in the theory of internationalization. The company's record of successful market entry, aggressive competition, and remarkably consistent financial performance all attest to the soundness of its unconventional internationalization strategy based on mergers and acquisitions (M\&As). This strategy will be referred to as a deep pockets strategy, signifying use of very substantial financial resources from sources such as family owners, individual investors, and bank loans as a means of buying entry into new markets. Success has also been gained from effective management, sound corporate governance, delivery of exceptional value-added services, and long-running partnerships with what the company calls its 'blue chip' customers across a vast geographic area (Times of Oman 2009).

\section{Case Study: Introduction of the Company}

Renaissance Services Company is primarily an oil and gas industry services company and is listed on the Muscat Securities Market in Oman. Oman is a large country with a very long coastline and an age-old tradition of sea-faring and trade with distant markets in Africa (especially Zanzibar), Asia (especially Balushistan), and Europe. It is an oil-exporting nation and a member of the Gulf Cooperation Council (GCC). This is composed of six nations around the Arabian Gulf, namely Oman, the United Arab Emirates (UAE), Saudi Arabia, Kuwait, Qatar, and the island nation of Bahrain.

Renaissance has an offshore fleet of vessels that provide a very broad range of support services to companies operating in seas and oceans where oil and gas are extracted and processed. Renaissance' service fleet is counted amongst the world's Top 10 in providing global oil and gas industry services (Financial Services Company 2007). The company offers engineering services in oil and gas fabrication; it repairs ships while afloat (called 'afloat ship repair'); it delivers a variety of turnkey services; and it competes in unrelated service industries such as advertising, media management, and human resource training. In 2008, Renaissance employed over 10,000 people, with offices in 18 countries and operations in 39 countries. Figure 1 presents a geographic profile of the global operations of the company. While many companies suffered severely during the economic crisis that started in 2007 and intensified through 2009, Renaissance reported record revenues in excess of US \$650 million in 2010 (Renaissance Services 2010).

\section{Insert Figure 1- here}

As part of its corporate commitment to improving the economic well-being and quality of life of all its stakeholders, Renaissance' Corporate Social Responsibility (CSR) program is designed to help people in economic or physical need, provide assistance to local communities, promote local employment, and showcase local talent in the arts and sport. It makes donations to local Omani charities and provides relief for humanitarian disasters abroad. In 2007 and 2008, one percent of earnings were invested in CSR programs, with plans to maintain this level in 2009. Interest in affirmative action for women was demonstrated by its US \$140,000 program to send the top ten graduating nurses from Oman's public university hospital (Sultan Qaboos University in Muscat) to attend a work placement internship at McMaster University in Canada in 2009 (Times of Oman2009).

\subsection{An Omani Entrepreneur with Global Ambitions}

As founder and Chairman of the company, Samir Fancy is the driving force behind the continued growth and success of Renaissance. With a professional background in finance and accounting, he started his first business in Saudi Arabia at the age of twenty-four. As a highly-motivated entrepreneur, Fancy moved back to Oman to join with family members in establishing The Tawoos Group, which provides industrial services, technology, media, and training services in Oman. "It was like a nursery where we grew many different businesses in the 
services sector," said Samir, attributing the Group's initial success to his brother who "provided the wisdom, guidance and capital that gave us the freedom to succeed."

In 1996, part of the family-owned company was taken public through a holding company structure. Renaissance Holdings was the first Omani family-owned company to be listed on the Muscat Securities Market. Despite a vibrant local market at that time, world realities soon changed as oil prices plummeted, credit lines hardened, the Omani Stock Market collapsed, and Renaissance found itself with big projects on hand as well as a mountain of debt. Consequently, chairman Fancy decided to engage the company in what he felt was 'the future.' "We decided to participate in bidding and won the contract to build all the permanent accommodation for contractors at Petroleum Development of Oman (PDO). This was a totally novel project for us." PDO is the Omani company that extracts and processes the country's oil reserves. It is majority-owned by the government with substantial stakes held by Shell and Total.

At that time, Renaissance was squeezed relentlessly by its banking partners. The difficult economy in Oman, new debt burdens associated with capital-intensive projects, and long lead times in getting paid for large projects were described by Fancy as follows: "I think probably, at that time, the most supportive banks were Bank Muscat in particular, and National Bank of Oman. They actually made an effort to understand our business, and that was extremely important to our future."

As business conditions improved, Fancy sought further opportunities for growth. While attending a course at Harvard Business School in 2005, Fancy developed the idea of focusing on providing safe, efficient, high-quality services to the oil and gas industry. A fellow course participant from Scotland was the Chairman of a company that owned a shipping fleet in the UK, BUE Marine Holdings. Over lunch the two businessmen identified an opportunity that Fancy and his team had been looking for. Renaissance had substantial cash reserves on hand and was keen to establish an asset base with an oil and gas industry focus. After careful consideration, the senior management team at Renaissance realized that a deal with BUE Marine fitted their plans perfectly. BUE Marine Holdings was acquired by a subsidiary of Renaissance (Topaz) in 2005, thereby allowing the company to enter the Caspian Sea market in Central Asia.

Samir Fancy was nominated by Ernst \& Young as a finalist in the Middle East Entrepreneur of the Year Awards for 2007 (Oman Daily Observer 2007). This award recognizes outstanding entrepreneurs on a regional and global level who are building and leading dynamic growing businesses. Reacting to the news of being selected as a finalist, Samir Fancy said, "All my life I have passionately believed in all that I did. I was perhaps blessed with an extra dose of courage. But the single-minded focus all this created never made life easy" (Times of Oman 2007a). Fancy explained how Renaissance was continuously adapting to the market environment and had reengineered itself to deliver better results.

"People are now seeing us differently and valuing us accordingly. Three years ago, Renaissance was an umbrella of four or five companies in a holding company model. That model is passed and today we are in businesses that have a clear focus. Our earnings have rocketed, and our vision for the future is based on clear and disclosed directions. Perhaps the most important attributes on this journey are courage and conviction," he explained (Times of Oman 2007b).

Today Renaissance is one of the largest exporters of services in Oman and one of the largest publicly-listed owners of foreign assets bringing profit and wealth to Oman. As Fancy stated in 2009:

"Looking ahead in investing for growth beyond this period, we are taking a stringent 'safety first' approach to new opportunities. Competitive tendering will continue to be a major source for growth and we stand confidently on our track record of contract retention and contract gains across all our services. Our services businesses continue to be a source of strong cash generation, not just in the larger companies but also in the smaller media and training businesses that continue to grow and prosper" (Times of Oman2009, p. 17).

\subsection{The Middle East Offshore Oil and Gas Services Support Industry}

More than 2,000 workboats are docked or repaired in the Middle East. These include offshore supply vessels, barges, dredgers, tugboats, and specialized craft. Christopher Hayman, Chairman of Seatrade, (organizers of '2008 Middle East Workboats' an annual industry conference), commented:

"The Gulf region has become a major centre for the workboat industry with multi-billion dollar projects in oil and gas, as well as port and waterfront developments around the Arabian Peninsula. Strong demand for offshore service vessels across the oil and gas sector, as well as for land reclamation projects, has resulted in a lack of capacity in the market. Some work fleets are outdated, being more than twenty years old. These factors have created demand for technically-advanced assets that can operate further offshore in harsh and physically 
challenging environments, so order-books of some shipyards are full until 2011" (Seatrade 2009).

Geir Sjurseth, Managing Director and Global Head of the Offshore Group at DVB Bank of Germany (which specializes in the global transport market) addressed the same conference in 2008. Sjurseth said: "More Middle East owners are keen on mergers and acquisitions to make an immediate impact in the markets. The market is oil-price driven and the offshore industry is seen as having long-term growth, with no sign of investment in oil and gas exploration and production cooling off or oil prices reducing. With business deals in other parts of the world drying up because of the credit crunch (2007-2008), the Middle East offshore marine market is seeing the introduction of significant private equity investment and is likely to see a wave of consolidation in the next few years" (Seatrade 2009).

During the economic crisis of 2009, Chairman Fancy remarked: "Our predominant presence in the growth areas of the Middle East and the Caspian, together sitting on more than $50 \%$ of the world's oil reserves, has meant that we are less affected than those with a larger presence in other declining oil and gas markets" (Times of Oman2009, p. 17).

\section{Company Organization for Services Marketing}

B2B services involve a wide spectrum of industries which has been described conceptually by Lovelock and Wirtz (2007) using a $2 \times 2$ matrix. One axis involves people or their possessions; the other involves tangible or intangible actions administered to people or their possessions. This classification identifies four types of services:

- people processing, with services directed at people's bodies (such as healthcare or lodging industries);

- mental stimulus processing, with services directed at people's minds (such as advertising or training);

- possession processing, with services directed at physical possessions (such as freight transportation, refueling, repair and maintenance, or warehousing and storage);

- information processing, with services directed at intangible assets (such as information technology (IT) services, banking, insurance, accounting, or research) (Lovelock and Wirtz 2007).

Renaissance is active in three of these four service sectors, excluding the first category. The sheer diversity of its activities represents a very significant challenge for company management to maintain competitive advantage, market share and profitability. A 2009 ad for the company in the New York Times illustrates the range of services offered, as shown in Figure 2.

\section{Insert Figure 2- here}

Figure 3 shows the organization of Renaissance Services into business divisions. These cover a highly diversified portfolio of service businesses operating across wide swathes of the world. Major business groups include the Marine and Engineering Group (MEG), the Contract Services Group (CSG), the Education and Training Group (ETG), and the Media and Communications Group (MCG). MEG generates 62 percent of the company's total business, CSG 27 percent, and ETG / MCG together account for 11 percent (Sing 2008). The leading division, MEG, is made up of three strategic business units under the umbrella-name of Topaz: Topaz Energy and Marine; Topaz Marine Services; and Topaz Engineering Services.

Insert Figure 3- here

\subsection{Marine and Engineering Group (MEG)}

In 2005, Renaissance Services merged with Topaz Energy and Marine, an Omani company, to create further capability not only in the Omani market but also in international markets. Through the merger, Renaissance diversified into many new business sectors and foreign markets. Topaz Energy and Marine operates in the Middle East, Central Asia, and Southeast Asia with over 5,500 employees and its headquarters are in Dubai, the major business city in the UAE. Activities include ship-owning, ship repair, oil and gas fabrication, and stainless steel production (Al Bawaba 2006a).

A sister company, Topaz Marine Services, offers a complete line of marine services to blue chip clients in the offshore oil and gas industry. The fleet is present in waters from the Middle East and North Africa to the Caspian Sea and beyond into South-East Asia. In addition, Topaz Engineering Services operates four businesses: fabrication and construction; vessel construction; marine repair; and maintenance services. There are plant facilities in the UAE for building sea-going vessels in Abu Dhabi (Adyard) and in Fujairah (Nico Fujairah). Clients include the on- and off-shore oil and gas industry, as well as process and heavy engineering industries (such as power generation and distribution) in the North Sea, Caspian Sea, and the Middle East. Repair 
workshops and service centers are located in Dubai, Abu Dhabi, and Fujairah (UAE), as well as in Oman, Azerbaijan and Kazakhstan.

\subsection{Renaissance Plan to List Topaz on London Stock Exchange}

As of early 2011 Renaissance formed Topaz Listco and was planning to list it publicly on the London Stock Exchange (Renaissance Services, 2011; Thompson, 2011). The company management was up-beat about this possibility. "The potential London listing of Topaz would be another transformational change for our business" said Mr. Fancy. "At the start of the global economic crisis, I wrote to you that we shall not waste this crisis - we have not. We emerge with our reputation sustained and enhanced, and the value of Topaz is expected to be recognized in a market where scrutiny is forensic and unforgiving" (Renaissance Services, 2010).

\subsection{Contract Services Group (CSG)}

CSG was originally established in Oman in 1986 under the name of Tawoos Industrial Services Company. Today, it is a major provider of contract services in the GCC and more distant markets. CSG can rapidly deploy emergency services to harsh or remote environments. Its business activities include a wide range of B2B services such as catering, cleaning, laundry, accommodation, operations and maintenance (O\&M), leisure, property, real estate, facilities establishment and management (known as 'build, own, operate' businesses). CSG's divisions include Norsk Offshore Catering in Norway, Renaissance Contracts Services in Qatar, and Renaissance Catering Company in Kuwait.

\subsection{Media and Communications Group (MCG)}

MCG has a range of media and business solutions to help client companies connect with their customers in Oman, Iraq, and Qatar. In Oman, two companies operating as United Media Services and United Press and Publishing serve clients in advertising, interactive marketing, IT solutions, public relations, events, publishing, media distribution and communication logistics.

\subsection{Education and Training Group (ETG)}

ETG consists of two companies: National Training Institute and National Hospitality Institute. These provide training and education in healthcare, safety and environment; driving and road safety; languages; IT; management; financial studies; customer service; hospitality; travel and tourism, as well as a wide range of industrial and technical vocational training courses. In addition to private individuals, ETG serves customers in the oil and gas industries, engineering and construction industries, banks, hotels, manufacturers, retailers, and many others. CSG operates primarily in Oman, Iraq, Norway, and Angola.

\section{A Bold Path toward Internationalization}

In going international, entrepreneur Samir Fancy displayed both courage and confidence. Growth was accomplished through frequent mergers and acquisitions. Some of the major events in the company's history during the period from 1997-2008 are outlined in Table 1. In the face of concern about Renaissance' dependence on income from short-term overseas contracts, at the end of 2001 a restructuring strategy was unveiled. This focused the company's attention primarily on the oil and gas services in order to serve several objectives:

- Build market leadership positions in current markets;

- Divest non-core businesses and investments;

- Take a disciplined approach to long-term investment in assets to serve the oil and gas sector;

- Create sustainable visibility through viable assets and long-term contracts with major international oil and gas producers;

- Generate funds for these investments through highly cash-generative pure services initiatives;

- Increase geographical spread in oil- and gas-based markets, with a balance between high-risk / higher-return and low-risk /lower-return environments.

With a large, diversified, and well-maintained fleet, Renaissance was already well placed to capitalize on market opportunities when rising prices for crude oil in 2007 were driving up global companies' spending on oil and gas exploration and production (Financial Services Company 2007).

Insert Table 1- here

\subsection{Norsk Offshore Catering}

In 2005, Renaissance acquired the entire share capital of Norsk Offshore Catering, a provider of drilling and production services in Tananger, Norway. The company took this strategic step as a means of entering the 
European oil and gas services market.

\subsection{Nico International}

Nico International (hereafter 'Nico'), a subsidiary of Topaz Energy and Marine, offers a wide range of engineering services for client vessels in France, Malaysia, and Singapore, as well as in Dubai. In the port of Bauatino in Kazakhstan, Nico plans to develop a repair yard with local partners. In 2008, Nico's General Manager remarked: "This will be our most successful year ever. In the first 10 months of the year, our Dubai workshop experienced 95 percent utilization, and there is no sign yet of any slowdown" (Seatrade 2009).

\subsection{Saudi Joint Venture}

In 2007, a joint venture was formed between Topaz and the Saudi company, Gentas Ltd. This company would own and operate vessels to meet growing demand in Saudi Arabia's expanding off-shore oil and gas exploration and production industries. "Topaz' move into Saudi Arabia is a natural extension for its off-shore vessel division which has been operating in the Gulf countries for over 25 years," said CEO Thomas. Topaz' venture partner based in Al Khobar in Saudi Arabia has subsidiaries in major Saudi cities such as Dammam, Riyadh, and Jeddah, as well as in London. It is active in the oil, gas, petrochemical, power and telecommunications sectors, in addition to undertaking private equity investments. Clients include global leaders such as Alcatel and Halliburton Energy Services.

\subsection{Doha Marine Services (DMS)}

Topaz Energy and Marine acquired Doha Marine Services (DMS) in 2008 for approximately US \$124 million. Doha is the capital city of Qatar, a member of the GCC and a leading world producer of gas products. DMS became the sixth operating company in Topaz' offshore vessel fleet serving the Middle East, the Far East, the Caspian, Kazakstan, and Turkmenistan with a seventh marine enterprise under formation in Saudi Arabia in 2008 (Renaissance Services 2008a). According to Chairman Fancy, "The DMS acquisition is a major event in our stated strategic intent to increase the size and geographical spread of our off-shore support vessel fleet." Renaissance' CEO, British-born Stephen Thomas, added:

"DMS is a debt-free company with a 2007 earning before interest and tax worth almost US \$17 million, which provides us with the base platform for growth. Together, the synergies and growth opportunities for DMS and Topaz are immense. Topaz brings scalability, flexibility, ambition, and a proven growth record, and DMS provides a superior route to market in Qatar and the Northern Gulf"' (Renaissance Services 2008a).

\section{Global Strategy and Performance}

Prevailing wisdom in the Middle East favors business diversification as a hedge against risk. In its early years, Renaissance appeared to follow this recipe for success. Later, chairman Fancy chose to go against the grain, refocusing his company's strategy on oil- and gas-related businesses by divesting operations in technology, media, and training services. Thus, in 2008 Renaissance accepted an offer from Services and Trade Sobha Group in Oman to acquire its technology business for approximately US $\$ 41$ million. In addition, a group of Omani investors acquired a 100 percent stake in United Media Services. CEO Thomas commented: "The decision to divest our technology, media, and training businesses is such a wrench at the emotional level. These are great, high-performance, high-potential businesses operated by first-class people. But, at the practical level, we believe they will prosper further in their own more specialist-focused environments, while we have turned our primary focus to oil and gas."

2010 was a record year for the company with total revenues of US $\$ 658.3$ million, up from US $\$ 643.1$ million in 2009. Net profit was US $\$ 83.9$ million, up from US $\$ 74.1$ million in 2009 . Operating profit increased by 20.2 percent, EBITA (earnings before interest and tax amortization) increase by 15 percent and operating margins improved from 16.4 percent in 2009 to 19.2 percent in 2010 (Renaissance Services 2010, p 2). The company's off-shore fleet of support vessels (OSV) dominates the Caspian region, with a 90\% market share in the Azerbaijani market and $41 \%$ in the Kazakh market. This success is due in particular to the nature of single-client dominance in the oil and gas fields. Thus, in the Azerbaijani market, Renaissance is $100 \%$ reliant on its contracts with BP, the global company that is already looking "beyond petroleum." In Kazakhstan, $56 \%$ of its business is with Agip-KCO and 33\% with Saipem. In Oman, 23\% of the company's Contract Services business is with PDO and its contractors, while $24 \%$ is composed of contracts related to the Government of Oman. In Norway, $80 \%$ of company business is with Maersk Contractors (Times of Oman 2009). These figures illustrate the deep significance of blue chip clients for Renaissance.

When announcing these stellar results in 2009, CEO Thomas observed: "While we remain alert to challenges in the current uncertain global economic environment, the Renaissance business model continues to show resilience 
to lower oil prices. In spite of greater scarcity and higher cost of financing, the company's growth plans remain on track, and the announcement of these preliminary results provides a clear signal of our ongoing progress in difficult times" (Times of Oman2009, p. 17).

Chairman Fancy commented on the nature of doing business in the oil and gas industry as follows:

"People look at our business and reasonably assume we are exposed to the oil cycle through our presence in the OSV, engineering and contract services businesses. Oil prices, order flows in the engineering business, credit cost and credit availability are all seen as critical factors for the company. Interestingly, oil price generally has little effect on our ongoing performance.

The Renaissance business model has proved itself to be remarkably resilient to boom and bust in the oil price cycle. Our markets, our blue chip clients, our predominantly long-term contracts and our assets are primarily focused in the development and production phase of the oil and gas industry. This is recognized as least sensitive to low oil prices.... We have strong and dependable cash flows sufficient to exceed all our obligations..." (Times Business 2009, p. 17).

With regard to the future, he added: "Renaissance companies bid for work at optimum realistic prices. Our 'close to the customer' credo does not indulge in opportunistic pricing, but rather is aligned in helping our clients achieve the safest, most efficient, lowest unit production cost in good times and bad. If anything, the recession is bringing into sharp relief the benefits of contracting with contractually compliant companies like those in the Renaissance group.....".

"Renaissance has a track record of strong year-on-year growth in all economic cycles - and it is through growth that we achieve efficiency in our group through scale, capacity, and redeployment" (Times of Oman2009, p. 17).

The company's business model has proven resilient to both high and low oil prices as its principal businesses (in offshore support vessel marine logistics, facilities management and life support services) are focused primarily on operations and production rather than exploration. Renaissance' engineering business is also well positioned as activities have been primarily moved from fabrication to maintenance.

\section{Planning for the Future Growth}

Renaissance' vessels operate in growth markets that currently account for more than 50 percent of the world's hydrocarbon reserves. Most of these involve long-term contracts with major global oil and gas producers, ranging from two to fifteen years. This reflects a strategic trade-off between high short-term profits and steady long-term profitability and visibility. Clients include industry leaders such as Agip KCO, Bechtel, BP, KBR, Maesrk, and Shell. Assets covered by these contracts include emergency response rescue vessels, barges, and equipment for cable laying and diving support.

In Oman, Renaissance works closely with PDO through its Contract Services Group which started construction of new facilities for industry contractors in the interior oilfields, under a US $\$ 86$ million program. This follows a 2008 contract with PDO to build, own and operate new permanent accommodation for contractors at Marmul and Bahja in Oman which will open for use in 2010. These contracts will run until 2044, with a contract-value for the initial 5-year period of more than US $\$ 91$ million.

Despite being in a massive asset acquisition phase, the company rejects any concerns about its debt-to-equity ratio. CEO Thomas commented on its deep pockets approach to business: "Our current gearing is less than one. Based on our current cash flows and the strength of the balance sheet, Renaissance can fulfill its entire declared investment program from a mix of internal surpluses and borrowings and still remain within all existing covenants with the company's bankers and remain within the debt-equity norm for the industries in which we serve."

Similar ratios for direct competitors in 2007 were Shiv-Vani (India) 2.8; DOF (Norway) 2.5; Deep Sea Supply (Norway) 1.9; Solstad (Norway) 1.3; and Renaissance (Oman) 0.8 (Financial Services Company 2007).

Renaissance operates in sectors and physical locations that are highly competitive and subject to sudden and unforeseen environmental changes. For example, from 2008 to 2009, the price of crude oil fell from a high of US $\$ 147$ per barrel to below US $\$ 40$ per barrel. Other uncertainties that the company faces include:

- $\quad$ Exposure to exchange rate volatilities;

- Lack of availability and high cost of financing in a post sub-prime crisis period;

- Rising inflation in key markets;

- Lack of availability of resources in the oil and gas sector (people, materials, or infrastructure); 
- $\quad$ Lack of availability of shipyard capacity;

- Potential over-supply of vessels in marine-based industries;

- Changes in patterns of demand for services, as a result of these factors;

- Negative volatility in the oil and gas sector, including volatility of oil prices.

During the period 2007-2009, Renaissance continued its expansion program, investing more than US \$116 million in 2007, with a total plan is to invest US $\$ 508$ million. A major part of the program involves acquisition of new OSV vessels in order to increase fleet size to around 100 vessels. Chairman Fancy observed optimistically: "The nature of the investments already made, the financial support already in place, the long-term tenure of secure contracts with blue chip clients and the continued vibrancy of the specific markets in which we serve, means that the Renaissance growth path is already secure and in place through 2009-2011" (Times of Oman 2009, p. 17).

\section{The Theoretical Discussion of Findings}

\subsection{Perceived psychic distance}

Figure 1 demonstrates the immense geographical dispersion of the company's activities across the world. The very nature of servicing ships at sea necessarily results in Topaz Marine Services operating in waters worldwide, from the Middle East and North Africa to South-East Asia. As shown in Table 1, M \& As led to entry in new country-markets as follows: Scotland in 2002, the UK in 2002 and 2005, Norway in 2006, and Qatar in 2008. Acquisition of BUE Marine in 2005 led to business in the Caspian region, while further acquisitions led to activities in Iraq, Azerbaijan, Kazakhstan, Turkmenistan, Angola, Norway, and Vanuatu. Given the type of industries in which Renaissance operates, CEO Fancy had little choice but to enter geographically distant areas of operation if he wanted his company to grow rapidly.

These findings suggest that perceived psychic distance has had little impact on Renaissance as it provides technical services wherever in the world they are needed. This is a very different business model from global consumer marketing, where success hinges on identifying idiosyncratic similarities and differences in consumers' tastes, lifestyles, and consumption patterns, followed by careful target marketing of company efforts. In such markets, managers may be hesitant to deal with distant markets where customer needs and competitive conditions are unfamiliar. In contrast, in highly technical B2B markets, business is much more similar across markets. This finding leads to the following proposition:

\section{Proposition 1: Psychic distance appears less problematic in the B2B sector than in the B2C sector.}

\subsection{Path toward internationalization using $M \& A s$}

Renaissance expanded internationally using a strategy of mergers and acquisitions. This strategy involves high-cost high-risk decisions and requires deep pockets or very substantial financial resources as a means of buying entry into new markets. Liquid assets, resulting from vast inflows of revenues into Gulf nations during periods of rapidly escalating oil prices, mean that $M \&$ As are being widely used to achieve rapid internationalization. In addition, family-owned resources are available to fund market opportunities, and friendly relations with major banks allow easy and timely access to loans. All of this evidence calls into question the validity of a gradual, stages-based approach to international market expansion for companies operating from bases in the Gulf, leading to a second proposition:

Proposition 2: The internationalization path model does not adequately explain cases where companies pursue rapid market entries through mergers and acquisition.

Renaissance provides a very broad range of technical services, from purely intangible people-oriented services to heavily product-based services. Evidence from the case study indicates that the company is highly successful in terms of company reputation, market share, profitability, and long-term orders. Through the M\&A strategy, Renaissance effectively acquires know-how in distant markets by allowing its companies to continue to be managed locally.

Proposition 3: Use of the M\&A strategy diminishes perceived psychic distance for the acquiring company through easy access to local human resources and institutional know-how.

\subsection{Country-of-origin (COO) effects}

Renaissance grew quickly from an entrepreneurial base, driven by the vision, courage, and confidence of its founder, an Omani. Consistent with prevailing business wisdom in the Gulf, the company became highly diversified across a number of unrelated service industries. Then the decision was taken to sharpen the business 
focus by concentrating on one sector, support services for the global oil and gas industries, producing very positive results.

It is notable that each company acquired by Renaissance continues to operate under its own name, effectively diminishing any $\mathrm{COO}$ effects that might be associated with new ownership by a company based in Oman. Moreover, divisions of Renaissance operate under names that do not suggest any obvious country affiliation (e.g. Renaissance, Topaz) but rather suggest a cosmopolitan character. In addition, the founder's country of origin (Oman) has been credited with allowing the founder to do business more easily and successfully with business partners in neighboring countries such as the UAE, Saudi Arabia, Qatar, Kuwait, and Iraq. The UAE, in particular, shares many cultural and business links with Oman. This leads to the fourth and fifth propositions:

Proposition 4: Oman enjoys a neutral or positive country of origin effect.

Proposition 5: Internationalization in the B2B sector is less sensitive to COO effects than in the B2C sector.

\subsection{Culturally-based values affecting entrepreneurial plans for growth}

In the case study, it was noted that culturally-based values in the Gulf shape entrepreneurs' plans for growth. These values are expressed as a preference for extreme diversification as a route toward rapid company growth and risk-spreading. In contrast to these findings, in their study of internationalization among Chinese entrepreneurs, Xie and Amine (2009) reported that respondents based decisions to go international on advice and information received through their social and business networks or guanxi. Those results contrast with findings from Elango and Pattnaik's (2007) study of Indian firms' membership in networks and business groups. These researchers investigated how members chose their overseas customers and markets and how they built global market portfolios. Elango and Pattnaik (2007, p. 551) concluded that “... certain assumptions and notions of the Uppsala model (i.e. deterministic sequential stages, commitment, state/change variables) need to be extended to incorporate the confluences of these linkages within a firm's network." Findings from those two studies, together with results from the present case study, all call into question the validity of internationalization theory as it is currently formulated. This leads to a sixth proposition:

Proposition 6: Strategic choices of entrepreneurs who decide to go international are shaped by local cultural values and business beliefs about best practices.

\section{Conclusion}

This paper presents a new case study of an entrepreneurial industrial services company which chose to internationalize from its base in the Gulf in the country of Oman. The case study shows that rapid growth was achieved by means of a deep pockets strategy of $M \&$ As, leading to a global presence marked by very positive financial and market performance, despite difficult economic times.

Based on evidence from the case study, we find that at least three theories in the field of international business do not, in their present formulation, adequately capture the new realities of companies expanding internationally from a base in a non-Western market. Specifically, our results call into question the completeness of psychic distance theory, especially in the context of the globalization of a services-based business where the service-provider must, literally, 'follow the business,' wherever it might be. Further, it appears possible to leap-frog over established stages of internationalization, particularly when using a growth strategy driven by mergers and acquisitions. A third finding is that little is known about country-of-origin effects associated with emerging nations which are home to entrepreneurs with global ambitions. Indeed, the Indian industrialist, Rajan Tata, recently shook the global automobile industry with his introduction of the super-low-cost micro-car, the Nano, which is 'made in India.' Tata has also declared an ambitious plan to quickly launch a more sophisticated version of the Nano in the EU, which is home to a highly competitive micro-car market.

Based on all of these findings, it is evident that existing theories in the IB literature do not fully accommodate the realities of companies and entrepreneurs outside developed nations who are taking different roads toward internationalization and global success. Further research is needed to test the six propositions formulated from this case study.

\section{References}

Al Bawaba. (2006a). Topaz Explores Investment Opportunities in Azerbaijan. London.

Al Bawaba. (2006b). Topaz in US $\$ 60$ million Fleet Expansion. London.

Amine, L. S. (2008). Country-of-Origin, Animosity and Consumer Response: Marketing Implications of Anti-Americanism and Francophobia. International Business Review, 17(4), 402-422. http://dx.doi.org/10.1016/j.ibusrev.2008.02.013 
Chetty, S., \& Campbell-Hunt, C. A. (2004). Strategic Approach to Internationalization: A Traditional Versus a "Born-Global" Approach. Journal of International Marketing, 12(1), 57-81. http://dx.doi.org/10.1509/jimk.12.1.57.25651

Elango, B., \& Pattnaik, C. (2007). Building Capabilities for International Operations through Networks: A Study of Indian Firms, Journal of International Business Studies, 38(4), 541-555. http://dx.doi.org/10.1057/palgrave.jibs. 8400280

Fina, E., \& Rugman, A. M. (1996). A Test of Internalization Theory and Internationalization Theory: The Upjohn Company. Management International Review, 36(3), 199-213.

Financial Services Company. (2007). Initiating coverage - Renaissance Services S.A.O.G: Rapid Transformation. Ruwi: Oman, June 2007.

Hallen, L., \& Wiedersheim-Paul, F. (1984). The Evolution of Psychic Distance in International Business Relationship. In I. Haag and F. Wiedersheim-Paul (Eds.), Between Market and Hierarchy (pp. 15-27). Uppsala, Sweden: University of Uppsala.

Jain, S. C. (1989). Standardization of International Marketing Strategy: Some Research Hypotheses. Journalof Marketing, 53(1), 70-79. http://dx.doi.org/10.2307/1251525

Johanson, J., \& Wiedersheim-Paul, F. (1975). The Internationalization of the Firm - Four Swedish Cases. Journal of Management Studies, 12(3), 305-22. http://dx.doi.org/10.1111/j.1467-6486.1975.tb00514.x

Khan, G. M. (2012). Internationalization of an Islamic Investment Bank: Opportunities and Challenges of Arcapita. In proceedings of AIB-MENA Conference, Dubai.

Khan, G. M., \& Al Moharby, D. (2010). Entry of Foreign Operators and Growing Competition Force a Domestic Company to Venture Overseas: The Case of Saudi Telecom Company. In proceedings of AIB-MENA Conference, Dubai, December 10-12, 2010.

Khan, G. M., Amine, L. S., Uddin, S. J., \& Zaman, M. (2011). The Internationalization of an Arab Bank: The Case of Ahli United Bank of Bahrain. Thunderbird International Business Review, 53(5), 581-600. http://dx.doi.org/10.1002/tie.20436

Knight, G., \& Cavusgil, S. T. (1996). The Born Global Firm: A Challenge to Traditional Internationalization Theory. Advances in International Marketing, 8, 11-26.

Knight, G., \& Cavusgil, S. T. (2004). Innovation Organizational Capabilities and the Born-Global Firm. Journal of International Business Studies, 35(2), 124-141. http://dx.doi.org/10.1057/palgrave.jibs.8400071

Liu, X., Xiao, W., \& Huang, X. (2008). Bounded Entrepreneurship and Internationalization of Indigenous Chinese Private-Owned Firms. International Business Review, 17(4), 488-508. http://dx.doi.org/10.1016/j.ibusrev.2008.02.014

Lovelock, C. H., \& J. Wirtz. (2007). Services Marketing: People, Technology and Strategy. New York, NY: Prentice Hall.

Masen, T. K., \& Servais, P. (1997). The Internationalization of Born Globals: An Evolutionary Process? International Business Review, 6(6), 561-584. http://dx.doi.org/10.1016/S0969-5931(97)00032-2

New York Times. (2009). Oman, Special Advertising Supplement (January 22).

Orbaiz, L. V., \& N. Papadopoulos. (2003). Toward a Model of Consumer Receptivity of Foreign and Domestic Products. Journal of International Consumer Marketing, 15(3), 101-125. http://dx.doi.org/10.1300/J046v15n03_06

Oviatt, B. M., \& McDougall, P. (1994). Toward a Theory of International New Ventures. Journal of International Business Studies, 25(1), 45-64. http://dx.doi.org/10.1057/palgrave.jibs.8490193

Pappu, R., Quester, P. G., \& R.W. (2007). Cooksey, Country Image and Consumer-Based Brand Equity: Relationships and Implications for International Marketing. Journal of International Business Studies, 38(5), 726-745. http://dx.doi.org/10.1057/palgrave.jibs.8400293

Prabhakar, M. (2007). As Good As It Gets. Business Today, (April 2007), 22-29.

Renaissance Services. (2006). Company Annual Report, 2006.

Renaissance Services. (2007). CEO Report.

Renaissance Services. (2007a). Company Annual Report, 2007a. 
Renaissance Services. (2007b). Renaissance Subsidiary Enters Angola, Company Press Release, March 14.

Renaissance Services. (2007c). Renaissance Subsidiary to Form Saudi JV, Company Press Release, September $30,2007 \mathrm{c}$.

Renaissance Services. (2008a). Renaissance to Acquire Doha Marine Services for QAR (Qatari Riyals) 453 million, Company Press Release, May 4, 2008a.

Renaissance Services. (2008b). Complete Entrepreneur, Company Record, 2008b.

Renaissance Services. (2009). Renaissance Announces Record Preliminary Results. Company Press Release, February 15, 2009.

Renaissance Services. (2010). Company Annual Report 2010.

Renaissance Services. (2011). Proposed Listing of Shares of Topaz Listco on the London Stock Exchange, February 27, 2011.

Rui, H., \& Yip, G. (2008). Foreign Acquisitions by Chinese Firms: A Strategic Intent Perspective. Journal of World Business, 43(2), 213-226. http://dx.doi.org/10.1016/j.jwb.2007.11.006

Seatrade. (2009). Nico Spreads Its Wings: UAE Special Report 2009. Marine Engineering/Shipping, 29-30.

Sing, M. (2008). Where Growth is a Way of Life. Oman Economic Review, May 2008, 88-91.

The AlAcra Store. (2009). Renaissance Services Mergers and Acquisitions. [Online] Available: www.alacrastore.com/mergers-acquisitions/Renaissance_Services-2561895 (February 16, 2009)

Thompson, C. (2011). Dubai's Topaz Eyes London listing. Financial Times, January 21, 2011, 16.

Times of Oman. (2007). Two Omanis in the Race for ME Entrepreneur of the Year Award, December 1, 2007a, p. 11.

Times of Oman. (2007b). Complete Entrepreneur, December 14, 2007b, p. 13.

Times of Oman. (2009). Chairman's Report. Renaissance Services SAOG, March 8, 2009, p.17.

Times of Oman. (2009). Renaissance Expects RO 26.2 Million Net Profit, February15, 2009, p. 24.

Xie, Y. H., \& Amine, L. S. (2009). Social Networks and the Internationalization of Chinese entrepreneurs. Global Business and Organizational Excellence, 29(1), 61-78. http://dx.doi.org/10.1002/joe.20299 
Table 1. Renaissance Services' Major Acquisitions and Divestments 1997-2008

\begin{tabular}{|c|c|c|c|}
\hline $\begin{array}{c}\text { Company acquired (A) / } \\
\text { divested (D) }\end{array}$ & Nature of business & $\begin{array}{l}\text { Acquired from / } \\
\text { sold to }\end{array}$ & $\begin{array}{c}\text { Date of } \\
\text { acquisition/ } \\
\text { divestment }\end{array}$ \\
\hline Al Wasita Emirates LLC (A) & Provider of contract services (UAE) & UAE & 2010 \\
\hline Doha Marine Services (A) & Provider of marine services (Qatar) & $\begin{array}{l}\text { Topaz Energy \& } \\
\text { Marines }\end{array}$ & May 4, 2008 \\
\hline IMTAC (D) & $\begin{array}{l}\text { Industrial management technology } \\
\text { and contracting }\end{array}$ & $\begin{array}{l}\text { Sobha Renaissance } \\
\text { Info Tech of India }\end{array}$ & April 2, 2008 \\
\hline $\begin{array}{l}\text { Norsk Offshore Catering } \\
\text { (A) }\end{array}$ & $\begin{array}{l}\text { Provider of drilling and production } \\
\text { services (Norway) }\end{array}$ & $\begin{array}{l}\text { Maersk Contractors } \\
\text { Norge }\end{array}$ & July 5, 2006 \\
\hline BUE Marine (A) & Marine support vessels (Scotland) & $\begin{array}{l}\text { I Group Plc., } \\
\text { Kleinworet } \\
\text { Wasserstein (UK) }\end{array}$ & July 17,2005 \\
\hline $\begin{array}{l}\text { Topaz Energy \& Marine } \\
\text { Services (A) }\end{array}$ & $\begin{array}{l}\text { Shipping, oil and gas services } \\
\text { provider }\end{array}$ & Oman & April 30,2005 \\
\hline BUE Marine (A) & Oil standby vessels & UK & May 31,2002 \\
\hline Garvel Clyde (A) & $\begin{array}{l}\text { Provider of ship building and repair } \\
\text { services (Scotland) }\end{array}$ & $\begin{array}{l}\text { Forth Group } \\
\text { (BUE Marine) }\end{array}$ & May 10,2002 \\
\hline Forth Estuary Engineering (A) & Engineering services (Scotland) & $\begin{array}{l}\text { Forth Group } \\
\text { (BUE Marine) }\end{array}$ & May 10,2002 \\
\hline Tawoos Industrial Services (A) & Industrial services & Oman & May 6, 1997 \\
\hline $\operatorname{IMTAC}(\mathrm{A})$ & $\begin{array}{l}\text { Industrial management and } \\
\text { technology and contracting }\end{array}$ & Oman & May 6, 1997 \\
\hline National Training Institute (A) & Training services & Oman & May 6, 1997 \\
\hline United Media Services (D) & Media services & Oman & May 6, 1997 \\
\hline
\end{tabular}

Source: The Al Acra Store: Renaissance Services Mergers and Acquisitions. Accessed February 16, 2009. www.alacrastore.com/mergers-acquisitions/Renaissance_Services-2561895.

Renaissance Services, Annual Report, 2010.

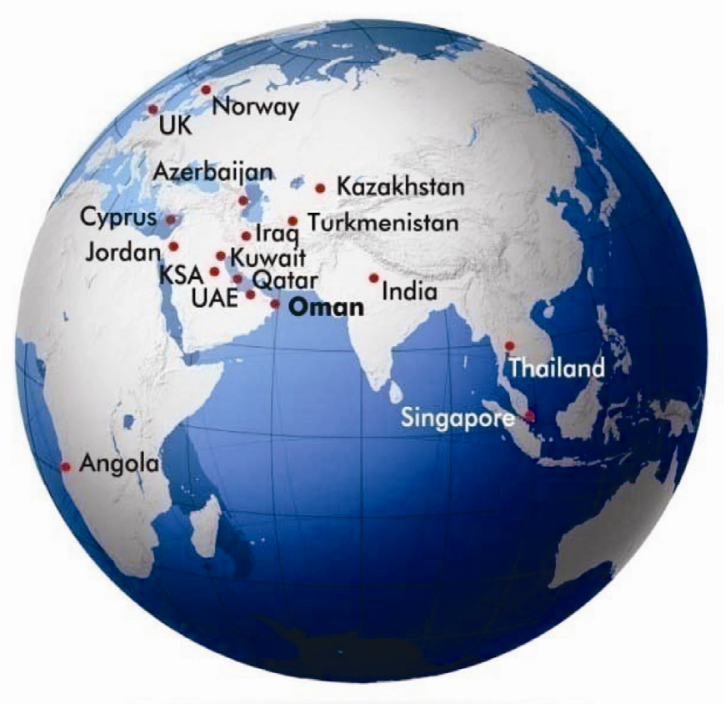

Figure 1. Map of Renaissance Services' Global Business Activities 


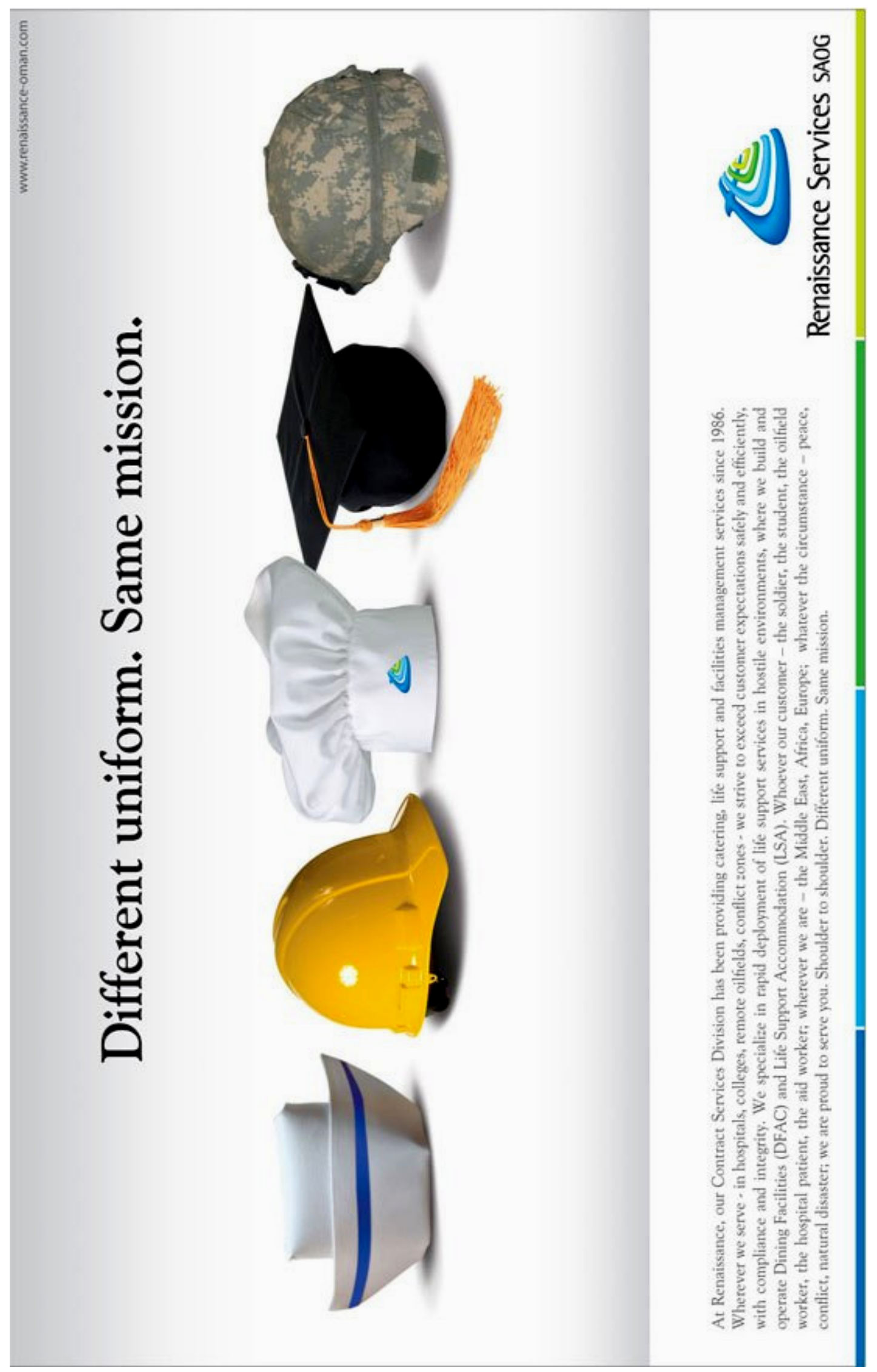

Figure 2. Print advertisement for Renaissance Services (New York Times 2009) 


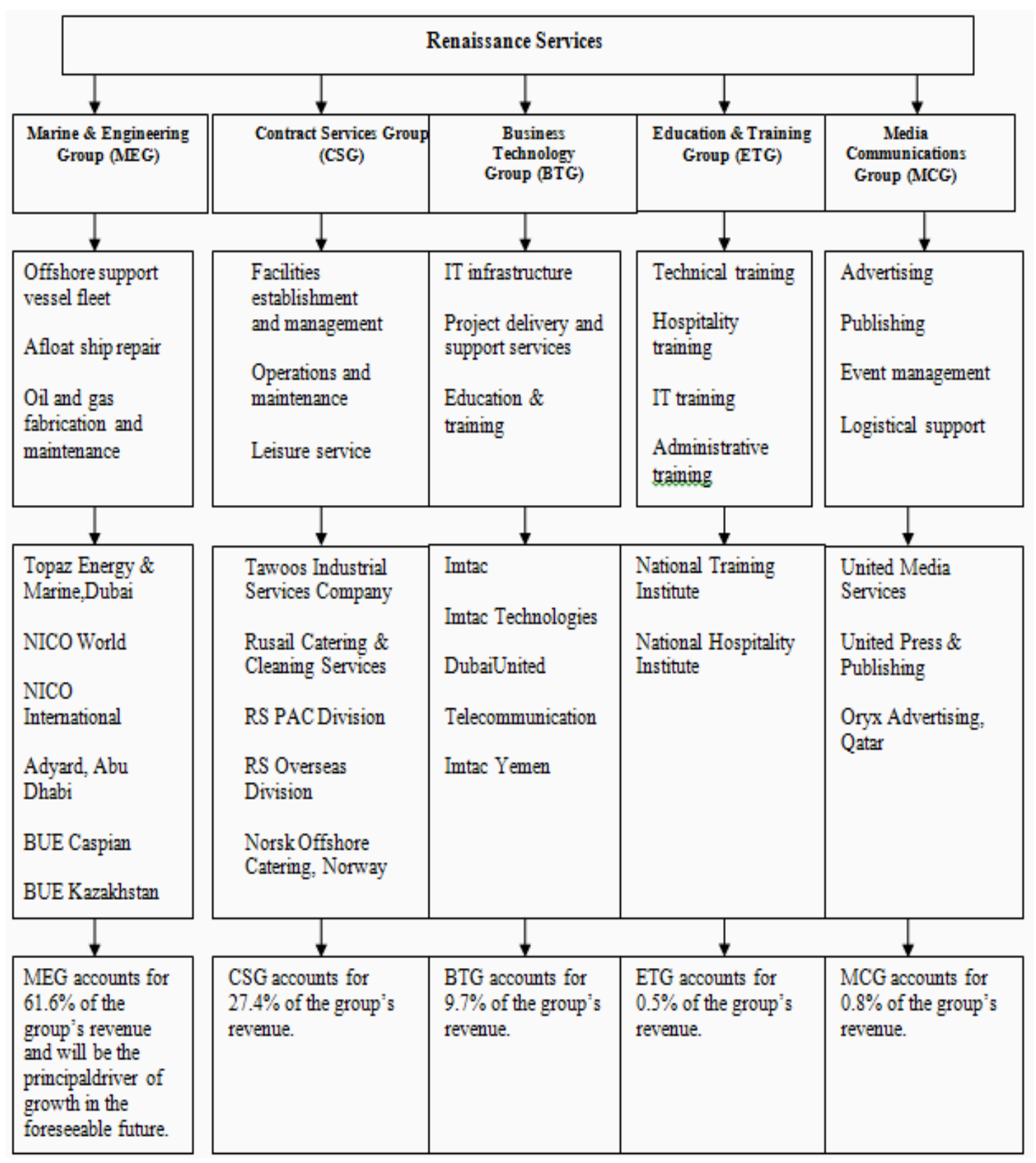

Figure 3. Renaissance Services' Group Structure

Source: Financial Services Company 2007 